This item was submitted to Loughborough's Research Repository by the author.

Items in Figshare are protected by copyright, with all rights reserved, unless otherwise indicated.

\title{
Voice, personality and Grandma: Mabel Constanduros and The Buggins Family
}

PLEASE CITE THE PUBLISHED VERSION

http://dx.doi.org/10.1080/2040610X.2016.1189178

\section{PUBLISHER}

Routledge, Taylor and Francis Group (@ 2016 Informa UK Limited)

\section{VERSION}

AM (Accepted Manuscript)

\section{PUBLISHER STATEMENT}

This work is made available according to the conditions of the Creative Commons Attribution-NonCommercialNoDerivatives 4.0 International (CC BY-NC-ND 4.0) licence. Full details of this licence are available at: https://creativecommons.org/licenses/by-nc-nd/4.0/

\section{LICENCE}

CC BY-NC-ND 4.0

\section{REPOSITORY RECORD}

Jeffs, Carolyn S. Scott. 2019. "Voice, Personality and Grandma: Mabel Constanduros and the Buggins Family”. figshare. https://hdl.handle.net/2134/21751. 


\title{
VOICE, PERSONALITY AND GRANDMA: MABEL CONSTANDUROS AND THE BUGGINS FAMILY
}

\author{
Carolyn Scott Jeffs ${ }^{*}$
}

School of the Arts, English and Drama, Loughborough University, Loughborough, UK

\begin{abstract}
This article explores the work of Mable Constanduros (1880-1957), who was a prolific writer and actress for radio, film and theatre, specialising in comedy. Her radio series The Buggins Family (over 250 episodes were broadcast by the BBC between 1928 and 1948) was possibly the first situation comedy, but has never been recognised as such. In this article I recreate scripts, analyse the structure of Constanduros's most famous Buggins episodes, and evaluate her performance, putting it into context with the wider culture in radio at the time. Frances Gray argues that sitcom is traditionally the preserve of men in her book Women and Laughter (1994), and that until very recently women have been regarded as contributing less to the genre, which could explain the reluctance to give Constanduros her true recognition. It is now commonly acknowledged that women have been victims of sexism in many ways and comedy writing is no exception. The men who were prominent in early radio comedy and drama are well known; the women are far less so. By evaluating The Buggins Family I hope to make Constanduros more visible, and in doing so add to the body of work that is challenging the male canon.
\end{abstract}

Keywords: Mabel Constanduros, comedy, sitcom, radio, performance, dramaturgy, cultural theory, reception theory, feminism

\section{Introduction}

Mabel Constanduros (1880-1957) was one of the most instinctive and natural performers in early radio. The Buggins Family (often called The Bugginses) was Constanduros's most enduring creation. In her autobiography she explains modestly that she 'had wonderful luck in that [her] work was unlike anyone else’s’ (Constanduros, 1946, 43). The programme was 'extremely popular with audiences as a result of its skilful characterization and gentle humour combined with sheer appreciation of Constanduros's acting skills' (DNB). She invented a cockney family because she felt that 'one voice [was] apt to become tiresome on the air if it [went] on for a long time' (Constanduros, 1946, 43). There were over 250 Buggins episodes

*Email: C.S.Scott-Jeffs @lboro.ac.uk 
broadcast between 1928 and 1948 (DNB). The most characters she ever played in one broadcast was seven and Constanduros developed this style of performance because 'being several people at once enabled [her] to do sketches', which she believed were 'more entertaining than monologues' (Constanduros, 1946, 43). By examining her work in the light of contemporary ideas we can reach an understanding of just how innovative she was in writing comedy and use of the voice.

Constanduros was already in her forties when she made her first solo broadcast for the BBC. Although the work was broadcast in the days of live performance, before recording became the norm, some sketches were recreated as gramophone recordings, and extracts from her grandson's collection of these can be heard on the BBC radio programme The Late Mrs. Buggins (British Library Sound Archive), which celebrates her life and work. These Buggins episodes were digitised in 2009 and are available in CD form. This has proved invaluable in understanding Constanduros’s performance style (Clark, Windyvar 46, 2009).

At the time comedy was considered to be an inferior genre. ${ }^{1}$ It might seem surprising that Constanduros managed to achieve so much success, but perhaps A. Corbett-Smith hit upon the reason in his article 'Do Women Want Wireless?' (Daily Express, 28 Feb, 1928):

[Women] want personality [...] Personality is the one big thing which counts in radio. And personality is the very thing that is so seldom found among the radio speakers and artists. You could count those with really vivid carrying power almost on the fingers of a hand.

Whilst the tone of the article was patronising like so many of the comments made about women by men of the period, Corbett-Smith identified the main factor responsible for Constanduros's achievements in the medium. The exaggerated yet recognisable personalities of her creations appealed to listeners, and in addition, despite the fact that Constanduros was playing characters, her own personality was also audible. As Susan Bennett points out in Theatre Audiences: A Theory of Production and Reception (1990, 162), 'performance encourages audiences to appreciate the actors' skill. Brecht stressed in his Verfremdungseffekt that the actor should "show" a character with the effect that the audience would appreciate the tools of acting used in this demonstration.' Bennett goes on to state that 'audience members might be attracted to the voice of a certain actor or to specific physical abilities' (162). This is also applicable to radio. Constanduros was able to use her vocal ability to 'show' her characters. The closest British performer we have to her style today is probably TV performer Catherine Tate. ${ }^{2}$ The audience derive as much pleasure from the personality that is performing as they do from the material that is performed; 'it is the tension between 
the real actor on the one hand, and the fictional character for who he functions as an iconic sign on the other, that creates one of the main attractions of [...] performance' (Esslin, 1988, 39).

\section{The Bugginses as sitcom}

Although The Bugginses are described as sketches they are actually more like what we would now call situation comedy (sitcom) in embryo form; 'the comedy [...] come[s] from the way [...] characters react to a situation and the way they react to each other' (Wolfe, 2003, 55). A sketch explores a comic moment where a sitcom tells a much bigger comic story (Vorhaus, 1994, 155). The complexity of The Buggins Family goes beyond the normal framework of sketch writing, which suggests that Constanduros wrote the forerunner of the 'domestic sitcom' with the 'husband, wife and kids', which has spawned so many permutations ever since (Wolfe, 2003, 55). Further evidence to support Constanduros as a writer of sitcom exists in the style of her work. Her scripts are not just a series of 'one-liners and gags strung together' (Wolfe, 2003, 29-31); The Buggins Family is funny because the characters are funny. Constanduros’s Buggins scripts are, in keeping with most definitions of sitcom, character-driven, in that 'the exploration of character is central, with the plot arising out of this' (Davis, 2001, 69). A normal family going to the zoo, having a picnic or catching the train is not particularly funny (although they may have their moments), but when the Bugginses attempt to do anything normal hilarity ensues. The situations created by Constanduros are real and normal for the period, but the characters are not. In addition,

Each [...] episode can be regarded as something like the last two acts of a traditional three-act play in that the characters and settings are already known to the audience. Not only are the characters known, but also their relationships and attitudes to each other (Wolfe, 2003, 31).

Constanduros also uses a format for her work, as defined by Wolfe (2003, 61-62), and The Buggins Family ‘involves a continuing cast of characters in a succession of episodes' (EB). This gives further support to its case for being a sitcom. Therefore I have analysed The Buggins Family according to comedy theory associated with the genre of sitcom, but first it is worth considering why this work has not been recognised as such.

According to the The Guinness Book of Sitcoms the first ever work of this type was That Child (1926) written by Florence Kilpatrick with Constanduros credited as an actor in the piece (Taylor, 1994, 250). For many years radio researchers believed that British sitcom began in the 1950s with Hancock’s Half Hour by Alan Galton and Ray Simpson, which 
started life on the radio and then transferred to television (Crisell, 1994, 168). The BBC website states that Pinwright's Progress, a TV Programme broadcast in 1946, was the first (25 April 2016). Constanduros's lack of recognition is possibly due to the ephemeral nature of the medium in which she worked. Almost all of her early work has simply disappeared from public view. Also The Buggins Family did not make the transition from radio to TV; sitcoms that manage to make this leap tend to be more widely recognised (BLSA, The Late Mrs Buggins). In addition the Buggins Family episodes were only about 3 minutes in length (The Buggins Family, CD), and sitcoms are ‘typically half an hour long’ (EB), so the brevity of Constanduros's work has perhaps been a factor in its lack of recognition in this category. ${ }^{3}$

There is also a more sinister possibility for Constanduros's lack of prominence. In Women and Laughter (1994, 81) Frances Gray argues that sitcom is traditionally the preserve of men and cites Mandie Fletcher's No Frills (1988), which was referred to as a 'feminist pilot' instead of a sitcom by the BBC because of the reluctance of BBC executives to accept women sitcom writers. Gray makes the point that, until recently sitcom has been thought of as something that is written only by men, which could explain the reluctance to give Constanduros her true recognition. Ironically Gray cites Hancock's Half Hour as the first sitcom too, so invisible has Constanduros become (Gray, 1994, 81). I hope that what follows will go some way to reinstating her.

\section{Recreating the scripts}

Sadly hardly any original Buggins radio scripts have survived, but there are a few short sketches available in pamphlets published by Samuel French. ${ }^{4}$ They were created for use by amateur theatre performers and adapted for the stage. Constanduros was adept at writing comedy for the ear and for the eyes and was able to convert one into the other with great skill. These provide a valuable record of the characters and dialogue, along with demonstrating the tone of the work, so I have used one called The Buggins Family Picnic in order to create a Buggins script. Original directions that are only appropriate for the stage are in bold print; directions in underlined italics are in the stage script, but also work on radio; directions in italics with no underline are what I have added to make the piece suitable for radio. I have also transcribed some examples from the recorded work on CD. In the transcriptions I have added my own directions in italics in order to indicate movement, sound effects, volume and intonation. 


\section{Structure and comic devices}

Vorhaus defines the comic premise as 'the gap between comic reality and real reality' in The Comic Toolbox (1994, 19-21). The Buggins Family is based on a strong comic premise, which is the gap between Emily's desire for happiness through improvement of her family and social position and the reality of the fact that this can never happen because her family have no desire to be happy or improve, socially or personally.

Wolfe offers a helpful guide to sitcom format in Writing Comedy (2003, 61-62). While each episode of The Buggins Family is different, there is a strict format that never changes. This is what sustained the series through 250 episodes. If The Buggins Family were a contemporary sitcom the format would be something like this:

- The Buggins family are working class cockneys

- They live in a small house, which is cramped because there are so many of them, causing overcrowding and conflict.

- The mainstay of the family is young mother Emily Buggins, who is old before her time.

- She is kind and dutiful and wants to make everyone happy.

- She has a strong desire for self-improvement, but doesn't really know how to go about this.

- Her problems are those associated with looking after her 3 children: a baby, a naughty little boy and a whiny little girl.

- She also has to keep house on a shoestring budget, for which she receives no thanks or recognition.

- She has to care for her cantankerous, deaf, elderly mother in law, who adds to her problems and causes a lot of conflict.

- Her husband is lazy, bad tempered and unhelpful, which causes even more conflict.

- No family members get on with each other, unless siding with someone against another, causing even more conflict.

It is the conflict that prevents the piece from ever becoming flat. Not only are the Bugginses in conflict with each other, they are also always in conflict with their living conditions and, more importantly, the world outside, which is vital in a successful sitcom (Wolfe, 2003, 60$61)$.

In The Bugginses’ Picnic, which is available in hard copy published by Samuel French (1930) not on CD, the family attempt an afternoon in the country. ${ }^{5}$ It may be based on Constanduros's first radio sketch, The Buggins Family Out for a Day, which was broadcast in 1925 (DNB). In this extract the family have just climbed a very steep hill to look at the view and have a picnic, which Emily believes will be good for them. This opening shows Constanduros's ability to create funny situations and truthful dialogue. It also demonstrates how the comic premise and format work; all except for Emily are utterly difficult and argumentative. 
(MRS. BUGGINS enters R. carrying several parcels and looking very hot. She is wearing a tightfitting velvet dress, a rather moth-eaten fur, and white canvas shoes.)

MRS BUGGINS. (very brightly) Coo! That was a climb! Come on, Father - come on, Gran'ma! It's lovely up 'ere.

(FATHER enters R. very slowly and very despondently and carrying a large bottle of beer in one hand and his collar and tie in the other. His bowler hat is pushed well back on his head, and he looks very hot.)

(Pointing up stage.) Isn't it lovely Father? Look at the beautiful trees and flowers and all the view!

(FATHER, apparently too disgusted to speak, makes no reply. He moves slowly across L., taking off his hat and wiping his forehead, whilst GRANDMA enters R. very slowly, carrying a basket. Her bonnet has slipped to oe side and her long, heavy black skirt looks very dusty; the neck of her old-fashioned boned bodice is undone, and her feather boa thrown back.)

(FATHER remains silent) Isn't it lovely Gran'ma? (slight pause) I say, look at the view! (GRANDMA remains silent)

(GRANDMA gives MRS BUGGINS a sour look and, ignoring the view, she drops the basket and wipes her forehead with her sleeve.)

Father, you might say somethink!

FATHER. (Staring disgustedly in front of him.) D’you mean to say we got to spend the whole day up 'ere?

MRS BUGGINS. (rather nervously). Yes - of course. It’s “Nature’s Paradise for Pleasure Seekers.” It says so on the Toobs. Don't you like the view Gran'ma?

GRANDMA.. (Without looking round.) Eh?

MRS BUGGINS. The view!

GRANDMA. Moo? 'Oo?

MRS BUGGINS. I said the view. It's simply lovely! And ain't that pond pretty at the bottom of the 'ill, there?

GRANDMA. Yes - swarmin’ with mosquiters and mi-asma, I lay!

MRS BUGGINS. Don't be silly Gran'ma! - I epect it’s full o’salmon! I call it lovely!

(Enter EMMA and ALFIE very weary, and carrying an enormous string bag overflowing with food. EMMA is wearing a white frock, much too short for her, black stockings and heavy boots, and a red tam-o'-shanter. ALFIE is in a sailor suit, and a large tweed cap of FATHER'S which nearly covers his eyes. His boots seem enormous for him.)

There children! Isn't the view lovely? What was it your teacher called it Emma?

EMMA. She said it was a u-nique panorama and a feast fer sore eyes.

FATHER. Yes - and a beast fer sore feet! (Glancing over his shoulder.) Look at it!

MRS BUGGINS. Well, wot's the matter with it?

FATHER. Wot ain't the matter with it? It's up a ridicklous 'ighth ter start with.

MRS BUGGINS. Well, you can't ave a view without an 'ighth can yer? Where would you like to sit, Gran'ma?

GRANDMA. I'm goin' to set ere! (She sits down R. determinedly.) That 'ills started me breakfast floatin', and I ain't goin' another step till it's perched.

MRS BUGGINS. Well, that's yer own fault fer eatin' so earty.

FATHER. Now, now, now! I don't come out fer the day to 'ear you two spite at one another - I can 'ear that at 'ome! (He turns up stage for the first time and looks down the hill.) Oh my goodness! Look at that beastly view! Not even a tram-line to cheer it up! - 'Ere, I can't look at it no more. It's turnin’ me. You know it always turns me to look down an ighth! (6-7)

Constanduros has used classic comic devices that work in any medium to great effect in this piece. The first and most noticeable device is called 'switching'; she has taken 'stereotyped, well-defined character[s] and switch[ed them] from their usual and familiar setting to a different one to see how they behave’ (Wolfe, 2003, 19). This is sometimes known as ‘clash of context' or 'the forced union of incompatibles' (Vorhaus,1994, 48). The comedy stems from the reactions of the family, particularly Grandma and Father, to their strange surroundings and each other. This is a device that is also used in episodes like At the Station 
(1927), which is set at a railway station; The Buggins Family at the Zoo (1928) and A Trip to Brighton (1932), the settings of which are in the titles (The Buggins Family, CD). By taking the family away from home Constanduros sets up more conflict with the world outside. Alternatively she brings the outside world to the Buggins family, as in Grandma's Birthday Party (1927); the quarrel that develops between Grandma and a wealthy visitor who was her 'girl'ood friend' is the cause of the conflict.

Secondly Constanduros uses ‘things going wrong', which create 'conflict, problems and complications' and the 'comedy [...] spring[s] from the reaction of [her] characters to these circumstances' (Vorhaus, 1994, 37). The family become locked in battle with the outside world. Beginning with Father's vertigo and Grandma's indigestion, the piece progresses from the characters' mild discomfort to farcical disaster as the bored children become glued together with flypapers:

(EMMA and ALFIE have been struggling with fly-papers and are now completely gummed to each other. One end of a streamer of sticky paper has twined itself round ALFIE'S neck, and the other is round EMMA'S, and they are standing back to back. The children approach struggling) EMMA. Oww... Stop pulling Alfie.

ALFIE. Oww...

(They begin to cry)

MRS BUGGINS. Oh, my goodness, what 'ave you done now?

FATHER. Ullo! Ullo! What's up now?

EMMA. A-Alfie and m-me s-s-stuck together with f-f-flypapers.

FATHER. (yelling with laughter). Look at 'em, Gran-ma! Stuck together like a couple o' blue-bottles. (GRANDMA chuckles)

MRS BUGGINS. Don't be so in'uman, both of yer!- great murderin' things.

EMMA: Get orff Alfie! (ALFIE screams)

MRS BUGGINS. No, don’t move, Emma! You'll tear Alfie's skin orf. You'll ‘ave to stay stuck now till it wears orf, or I get you both into a 'ot bath. Oh, sit down back to back, and stop owlin', do! (12)

As the family try to have their picnic Constanduros skilfully uses 'things going wrong' to put more and more pressure on her characters: the butter melts, the ham is off, the salmon can't be eaten because they have forgotten the tin opener and Father injures his hand trying to open it with a stone, then the fried fish gets covered in paraffin. Eventually they are left with only bananas and a few shrimps, which are Grandma’s. Father is determined to eat the salmon and sets about getting it open. Like the hill and the flypapers this visual gag works remarkably well on radio because Constanduros supplies enough dialogue to indicate the situation and the listener's imagination does the rest:

MRS BUGGINS. Try stampin’ on it, Father.

(FATHER puts the tin behind the tree-trunk and, with his back to the audience batters it with the heel of his boot)

Go on, Father!- It's dentin'

(sound of battering tin) 
EMMA/ALFIE. Go on, Daddy!

(more sounds of battering tin and groans of exertion from FATHER)

EVERYONE. Go on - go on!

FATHER. (in great excitement) It's goin' - it's goin'! It's - Oh! (he claps his hand to his eye in agony) Argghh...

MRS BUGGINS. Whatever's the matter, Father?

FATHER. Me foot's gorn through the tin, and the juice'as squirted in me eye!

GRANDMA. (complacently) Oh, that's nice! Now we can 'ave a dob o' salmon!

FATHER. Oh - oh - oh! - it's cut right through me boot.

(When FATHER holds up his foot, a battered tin is seen on the heel of it, which has been

concealed behind the tree-trunk and substituted at this point for the original tin.)

MRS BUGGINS. Oh, do stop 'owlin', Father, and take that tin orf the endo of yer foot. The salmon'll

be ruined!

FATHER. (hopping) It won't come orf, I tell yer, - it won't come orf! It's cut right through the boot inter me flesh!

MRS BUGGINS. Oh, good gracious, Father, what are we to do! For goodness sake don't put it to the ground - the salmon'll eat in.

GRANDMA. (enjoying it) Let's 'ope it ain't the gangrenious sort, that's all.

MRS BUGGINS. Oh, good 'eavens! We'll 'ave to find a doctor. - Don't put it to the ground, Father you'll 'ave to 'op.

FATHER. 'Op! All down that great 'ill? What d'yer take me for? - a kangaroo?

MRS BUGGINS. Oh, don't wait to argue, Father. It may be turnin' gangrenious this very minute, and 'eating inter yer cistern. Come on - you 'op, and I'll give you me arm.

(MRS BUGGINS puts FATHER'S arm around her neck, and he leans heavily upon her, groaning hollowly)

GRANDMA. Oh, stop groanin', fer goodness sake! Ere's me rusted up ter the gullet, and never a sound outer me.

FATHER. Well, you never ‘ad a ingrowin’ salmon on yer foot! (16)

On radio there is no need for the clumsy and unconvincing substitution of the tin.

Constanduros was also adept with the 'wildly inappropriate response' (Vorhaus, 1994, 50). In the first extract Father and Grandma laugh at the distress of the children. In the second Grandma remains unsympathetic and is unmoved by Father's agony. She then adds to his woes by exaggerating the possible consequences of the situation, suggesting he might get gangrene. Emily's response swings from an inappropriate concern for the condition of the salmon over that of her husband to over-anxiety about his health, fuelled by Grandma's pessimism. It is the overlapping of all these devices that contributes to the hilarity of the piece.

\section{Characters and the underlying sadness}

Much of the humour in The Bugginses rests on Emily's determination to improve them all and create happiness. This is a well-worn theme in contemporary sitcom writing; Emily existed before Ria in Butterflies, Margo in The Good Life and Ma Boswell in Bread. ${ }^{6}$ Each of these characters is 'the lynchpin [...] of a family surviving in a hard economic climate' (Gray, 1994, 97). Vorhaus believes that fundamentally 'comedy is about truth and pain' 
(1994, 1-8). This was something Constanduros had a particular understanding of. The character of Emily can never accept the truth that her family simply do not share her enthusiasm for life or want to improve; they refuse to be happy, which causes her endless pain of disappointment. This simple comic device is at the heart of The Bugginses and is used to fuel the plots. Emily's desire to make her family appreciate a day out in the open is a running gag throughout The Bugginses’ Picnic. Even when the situation is resolved by the family leaving the scene of misery and heading for familiar surroundings Emily's desire for better things remains unresolved and carries the sitcom forward into the next episode. The conflict that is crucial to the success of The Buggins Family is never entirely resolved.

The futility of Emily's attempts at improvement creates real pathos, which is evident in Grandma and Father too; when 'a character [...] is both funny and at the same time pathetic, the combination [is] very moving' (Davis, 2001, 141). Grandma is at once hilarious and sad; she is bewildered by the changing times and is desperately trying to control her tiny world. She is genuinely fearful concerning her health because of her age, and this fear creates her negative approach to everyone else's health, along with a tendency to be spiteful. She is a prophet of doom who takes advantage of Emily's anxiety and lack of education to constantly cause trouble. Grandma's inflexible personality provides an effective block for all of Emily’s attempts to find joy. This is not dissimilar to the relationship between Harold and his father, Albert, in Steptoe and Son, the 1960s sitcom about two rag-and-bone men, by Alan Simpson and Ray Galton (BBC, 1962-1974). Harold's attempts to improve are always thwarted by his father, but they remain locked together because ultimately they only have each other (Davis, 2001, 141). The sad truth in The Bugginses is that Grandma only has her family and is entirely dependent on them. Father and Grandma form a double obstacle that Emily's optimistic personality has to overcome on a daily basis. Father is desperately sad due to his lack of education and mundane job in a warehouse; his pigeons provide his only comfort. Without Emily he would be unable to function (Constanduros and Hogan, n.d.). Like Steptoe and Son 'if it weren't so funny it would be tragic' (Davis, 2001, 141).

\section{Class and language}

Rib Davis $(2001,14)$ explains that 'class is hugely important in terms of how characters are perceived and how they perceive themselves.' At the time Constanduros was writing class structures were more rigid and the Buggins family fitted into the working class because Father, the main breadwinner, earned a living in a low-skilled, low paid job (Pugh, 2009, 76- 
101). In creating the Bugginses, Constanduros managed to poke fun at everything the BBC was attempting to do. It may have been deliberate satire or simply accurate observation. Emily represented the kind of housewife that the BBC wanted to educate. ${ }^{7}$

Davis $(2001,15)$ points out that 'while a particular class is something we are born into, it is also something we may move away from, either in fact or in our own perceptions.' This is 'one of the most fertile areas for the creator of character' and it is certainly exploited by Constanduros, who uses the discrepancy between what Emily wishes to become and what she actually is to great comic effect. The Buggins family's lower class status is 'defined through income, lifestyle, [Father's] occupation' and, of course, education (14). This affects the way that all of the characters speak and act, which brings us to the way Constanduros uses language to create humour in The Bugginses. Wolfe (2003, 33) makes the point that 'in England especially, you learn a great deal about a person the moment they start speaking.' Constanduros uses 'accent, grammar, articulation, manner of speech [as] a giveaway to background, education and status' (33).

The comic device of the malapropism (from the name of the character Mrs Malaprop in Sheridan's play, The Rivals, 1775) is a favourite of Constanduros. This type of comedy of language is particularly radio friendly. Helitzer (2005, 333) defines the 'malaprop' as 'the use of twisted language that is innocently spoken by an ignorant person.' The following extract demonstrates how Constanduros uses mistakes in language for Grandma and the inverted snobbery and lack of education of Father to equal comic effect:

FATHER. [To the children] 'Ere the pair of yer can take and carry the dinner over to them gorze bushes, where I can't see this beastly panamara. I'm turnin' that giddy, I shall get an attack of the verdigrease and precipitate meself down it in a minute.

GRANDMA. I ain’t settin’ by no gorze bushes!

MRS BUGGINS. Why not Grandma?

GRANDMA. Swarmin' with snakes and evvets, they are. I knoo a girl wot sat under a gorze bush and a evvet popped out and bit 'er, and she was never the same again.

FATHER. Ah-two-legged evvet I expect that one was!

GRANDMA. No, it wasn't, then! It was a ordinary gastronomic evvet. (7)

Andrew Crisell $(1994,167)$ attributes this kind of witty language to what he calls the 'newer, radiogenic form of comedy' in which words themselves are used to create humour, citing The Goon Show as a prime example (BBC Home Service, 1952-1960). ${ }^{8}$ Constanduros was ahead of her time in her use of language on the radio. ${ }^{9}$ 


\section{Grandma}

Grandma is probably the most recognizable and funny of all the characters. Early radio theorist Filson Young $(1933,245)$ describes her as 'an embodiment of complete selfishness and malice, and so mean and squalid in her habits as to be physically revolting.' The important words here are 'embodiment' and 'physically' because they indicate that Grandma's success is partly because of the image she creates in the mind. There is something about the creaking voice and sigmatic (whistling) s (which developed over time) that effectively conjures the image of a '[bonneted old woman wearing a] heavy black skirt, [...] old-fashioned boned bodice [...] and feather boa'. 10 The comedic physicality of this personality is brought into existence by the invention of the mind. Voice is recognised in stand up comedy as 'the most important physical instrument for conveying character’((Hellitzer, 2005, 242). This 'physical instrument’ if used with sufficient skill, can be the best tool for creating character on radio because 'voice inflection, from malicious cackling to nasal whines, indicates personal characteristics not physically evident' (242).

And Grandma not only spoke with a distinctive voice that gave clues to her personality, she also said things that only Grandma would say like, 'When you've got a 'usband you lose yer tase fer 'em' (BLSA, The Late Mrs Buggins). In creating Grandma Buggins Constanduros was employing what Frances Gray $(1994,8)$ calls the 'Mrs Grundy’ technique, which is often used by male comics as a way of defending sexist jokes. Grandma Buggins is the epitome of 'a thin-lipped and humourless prude averse to any form of spontaneity, life or joy.' But Constanduros does not use this character in a way that is cruel, as Gray believes some male writers might: 'the nagging mother-wife, reducing male energy to domestic tidiness, sexually rapacious or coldly puritanical' (85). Instead Grandma Buggins is used to highlight the differences between the generations. The extraordinary respect and affection granted to Grandma by her daughter-in-law, Emily Buggins, and the rest of the family, is sincere and reflective of the period. It was a time when many families were living under the same roof as at least one elderly relation (Gale, 1996, 21-37). As Barry Cryer comments, 'Mabel got the generation clash; she had an astonishing ear for subtle nuances of speech’ (BLSA, The Late Mrs Buggins). Audiences of the time almost certainly concurred with Gray's opinion that 'there is an undeniable pleasure [...] in the comic skill with which these comic stereotypes are portrayed; [...] they offer a vehicle for the vitality of an authoritative performer' (86). Earlier I discussed an article written in 1928 by A. Corbett

Smith in which he states that the most important thing in radio is 'personality'. Replace Gray’s ‘vitality’ with Corbett Smith’s ‘personality’ to explain the success of the series with 
that particular audience. Both Constanduros and the people she created had some of the most distinctive characteristics on radio, but it was probably her own personality that led to her stardom; Esslin $(1988,59)$ asserts that 'a far greater proportion of audiences [want] particular actors rather than the characters they signify.' Constanduros was giving listeners what they wanted in the form of The Buggins Family, which provided the vehicle for her unique ability.

\section{Conclusion}

Constanduros created some of the earliest funny characters and situations for radio. Val Gielgud noted in 1932 that 'Miss Constanduros [...] proved that it is perfectly possible to write humour indigenous to the microphone.'(Gielgud, 1932, 35) Her comedy has stood the test of time, and is still funny today, yet she remains overlooked. She wrote about class and gender using ‘jokes [as] the bridge’ (Gray, 1994, 15). It may be that much of her work has been forgotten because, as Gale puts it:

Domestic [...] pieces are regularly assumed to be the place where the "trivial” concerns of women's lives, of interest to a "minority", are played out. Thus many of the plays by women, because they take “domestic life" as a starting point, have been considered unworthy of critical analysis (1996, 7).

The fact that Constanduros was a woman was almost certainly a factor in her lack of recognition. Recent studies on gender in the arts are proving that women have been discriminated against. Gray's theory is probably correct and a qualitative analysis of sexism in comedy is overdue. This article has attempted to redress the balance and show Constanduros as a consummate writer, performer, and observer of human nature. I hope it will inspire further research into Constanduros’s work and the origins of sitcom writing.

\section{Acknowledgements}

I would like to thank the staff at the BBC Written Archive Centre and the British Library Sound Archive for their help with sourcing the original recordings and documents that have contributed to this article. Thank you also to Professor Mick Mangan for supporting and encouraging my work on women and radio throughout my $\mathrm{PhD}$. Above all else my gratitude goes to my incredible husband Anthony Walters and my extraordinary daughter Lizzie Wofford; their unfailing interest in my research continues to inspire me to rediscover the work of forgotten women. 


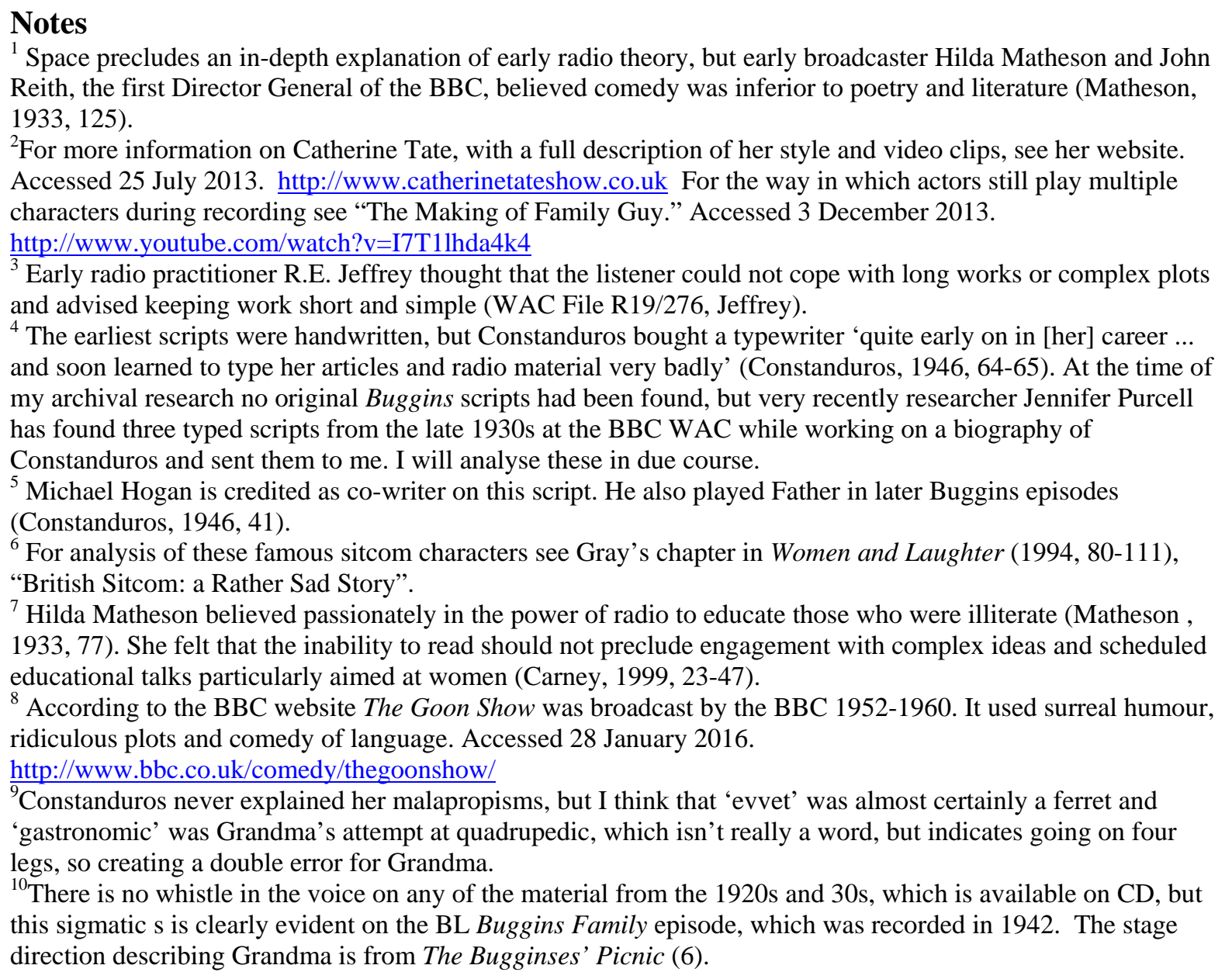

\section{Disclosure Statement}

No potential conflict of interest was reported by the author.

\section{Notes on contributor}

Carolyn Scott Jeffs is a playwright and lectures in Playwriting and Dramaturgy at Loughborough University. She writes for TV, radio, and the stage. Her plays for BBC Radio 4 include Jesus, The Devil and a Kid Called Death, 15 Ways to Leave Your Lover, 21 Conversations with a Hairdresser, Tarnished Wings, Angel of New Street and Square Circle Triangle. She has written for the BBC continuing drama Doctors. Her work for the stage includes the hit comedy Out in the Garden. She is resident dramaturg at London Theatre Workshop (http://londontheatreworkshop.co.uk/). Her latest stage play, The Fanny Monologue, is scheduled for production later this year.

\section{References}

Bennett, S. 1990. Theatre Audiences: A Theory of Production and Reception. London: Routledge. Carney, M. 1999. Stoker. Wales: Carney. Constanduros, M. 1946. Shreds and Patches. London: Lawson and Dunn. Constanduros, M., and M. Hogan. n.d. The Bugginses. London: Hutchinson and Co Ltd. Constanduros, M., and M. Hogan. 1930. The Bugginses’ Picnic. London: Samuel French Ltd. Crisell, A. 1994. Understanding Radio - Second Edition. London: Routledge. Davis, R. 2001. Developing Characters for Script Writing. London: A\&C Black. Esslin, M. 1988. The Field of Drama. London: Methuen. Gale, M.B. 1996. West End Women: Women and the London Stage 1918-1962. London: Routledge. 
Gielgud, V. 1932. How to Write Briadcast Plays. London: Hurst and Blackett. Gray, F. 1994. Women and Laughter. Basingstoke: The Macmillan Press Ltd. Helitzer, M. 2005. Comedy Writing Secrets. Cincinnati: Writer’s Digest Books. Matheson, H. 1933. Broadcasting. London: Thornton Butterworth.

Pugh, M. 2009. We Danced All Night: A Social History of Britain Between the Wars. London: Vintage. Taylor, R. 1994. The Guinness Book of Sitcoms. London: Guinness Publishing Ltd. Vorhaus, J. 1994. The Comic Toolbox. Los Angeles: Silman-James Press.

Wolfe, R. 2003. Writing Comedy. London: Robert Hale Ltd.

Young, F. 1933. Shall I Listen. London: Constable and Co Ltd.

\section{British Library Sound Archive Sources}

The Buggins Family. Mabel Constanduros. 1942, MP 4252

The Late Mrs Buggins. Radio programme. BBC Radio 4. Broadcast Sunday 5 March 2006

\section{BBC Written Archive Centre Sources}

Constanduros, Mabel: Copyright File 1A, 1926-1938

P129, Press Cuttings, Programmes, 1926

Jeffrey, R.E. n.d. Notes on Techniques of Boadcasting. File R19/276 'Entertainment: Drama Department 1924948'.

\section{CD}

Constanduros, Mabel. The Buggins Family. 'Windyridge Variety Series'. William/Clark: WINDYVAR46, 2009.

\section{Internet Sources}

"The history of sitcoms and the British at work.” BBC Website. Accessed 2 May 2016.

http://www.bbc.co.uk/news/uk-12692104 